\title{
METHODS OF HEALTH INSTRUCTION IN THE FOURTH AND FIFTH GRADES
}

\author{
CAROLYN HOEFER \\ Elizabeth McCormick Memorial Fund, Chicago
}

Articles in the September and November issues of the Elementary School Journal discussed the problem of placing more emphasis on health instruction in the first, second, and third grades by combining certain health essentials with the material used in other subjects. This article will discuss the same problem in connection with the work of the fourth and fifth grades.

\section{A. HEALTH PRINCIPLES TO BE TAUGHT IN THE FOURTH AND FIFTH GRADES}

The essential ideas suggested for the first three grades included (I) going to bed at seven or eight o'clock, depending on the age of the child, (2) drinking milk three times daily, (3) brushing teeth every night, (4) drinking a glass of water before breakfast, (5) eating cooked cereal every morning, (6) eating fruit once a day, and (7) eating at least two vegetables every day, one of which may be potatoes. What, then, are the leading principles to be emphasized in the fourth and fifth grades?

There are three health rules which should find a place in these two grades, first, because their importance demands that they be placed early in the curriculum and, second, because they can easily be adapted to the work of these grades. These rules emphasize the importance of (I) having fresh air at all times, especially at night, (2) eating no sweets between meals and reducing the amount eaten at meals, and (3) eating meat only once a day.

It is impossible in a brief article to give all the reasons which should justify the placing of any fact in the list of minimum

I This is the third of a series of articles on classroom methods for increasing the efficiency of health instruction in the public schools contributed by the Elizabeth McCormick Memorial Fund. Reprints of these articles may be obtained from the Elizabeth McCormick Memorial Fund, 848 North Dearborn Street, Chicago, Illinois. 
essentials of a scientifically formed course of study. However, in order that the teacher may realize the importance of forcefully teaching these rules, Figures $I$ and 2 are presented. Figure I is based upon data from the Mortality Statistics of the United States Department of Labor for the years I900 to I9I9, inclusive. Figure 2 is based upon data from the Statistical Abstract of the United States, I920. ${ }^{\mathrm{X}}$

Figure I shows that while the rate of deaths resulting from tuberculosis is on the decrease, it is still too high to be overlooked in planning a course of instruction in health. Incidentally, it

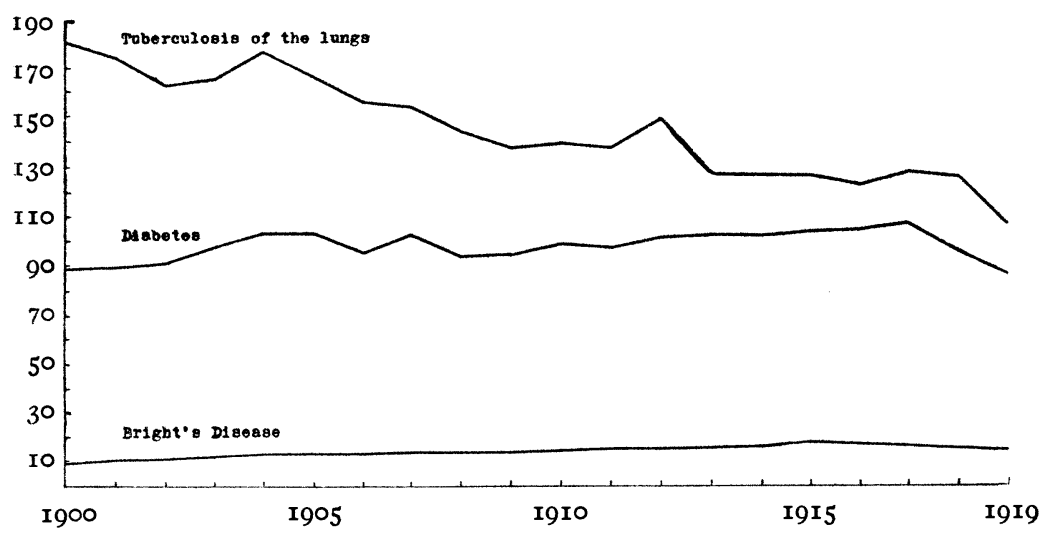

Fig. I.-Number of deaths per 100,000 resulting from tuberculosis of the lungs, diabetes, and Bright's disease from rgoo to r9r9, inclusive.

may be stated here that it is not intended that these facts be given to the children, as only the positive and brighter side of education should always be presented to them, but it is felt that the teachers should be in possession of such facts so that they may more fully realize the responsibility which is placed upon them and that they may have a clearer vision of the future of those who come under their care.

Fresh air, especially in the classroom and at night, is generally recognized as a preventive of tuberculosis. Significant facts regarding methods of classroom ventilation are presented in an article by Dr. Josephine Baker, director of the Bureau of Child

${ }^{2}$ Pp. 552-53. 
Hygiene, New York City, published in the American Journal of Public Health, January, I918, and in a pamphlet, Natural Upward Ventilation, published by Samuel Wheeler. ${ }^{\text {I }}$

The second and third rules suggested for the fourth and fifth grades need, perhaps, a little more explanation to justify their position in the course of study. Figure I shows an increase in the rate of deaths resulting from diabetes and Bright's disease and raises a question as to possible causes according to the latest information from those who are specialists in this field. Two

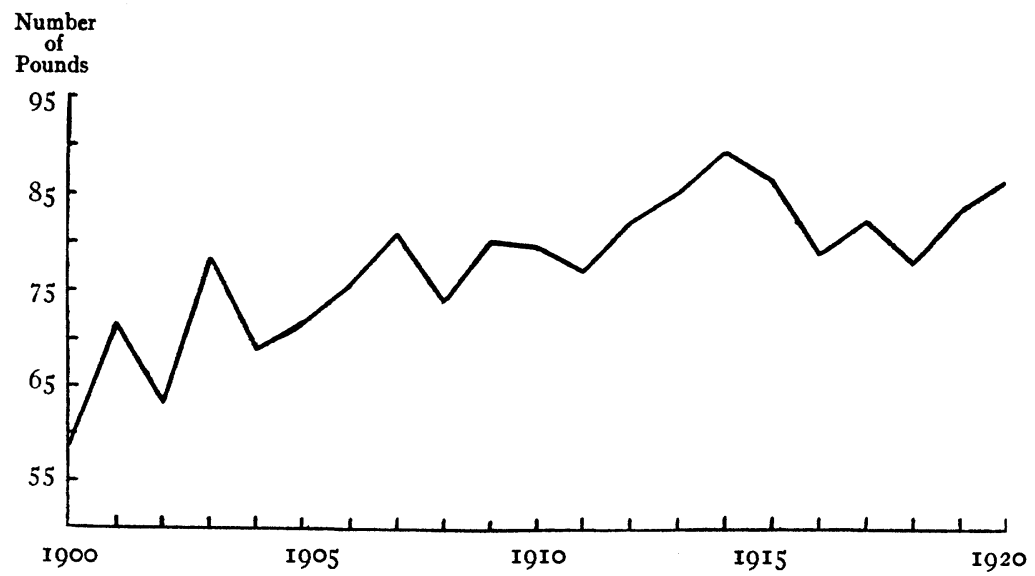

FIG. 2.-Per capita consumption of sugar in the United States from rgoo to 1920, inclusive.

quotations from medical writers will partially answer this question. Dr. R. L. Alsaker, in writing upon the method of treating these diseases, says,

Both of these ills have been looked upon as incurable down to the present time. ... . Correct living and especially correct eating will result in a cure. . . . . Temporary diabetes may be produced by too great intake of sugar, in any form, such as refined sugar. . . . . Bright's disease is a symptom of degeneration of the entire body. About roo,000 individuals annually die in our country from Bright's disease and acute nephritis (inflammation of the kidneys), about nine-tenths of these deaths being due to chronic Bright's disease, nearly all of which could be prevented. . . . . It is true that those who suffer from this disease are generally excessive eaters of protein, especially of

${ }^{1}$ Reprints of these articles may be obtained from the Elizabeth McCormick Memorial Fund, 848 North Dearborn Street, Chicago, Illinois. 
meat. . . . . It is not necessary for meat eaters to give up flesh entirely but it is necessary for them to quit overeating. . . . . Those who can have cooked greens such as spinach, kale, beet tops, chard, turnips, or dandelions should eat them often-every day would be all right. ${ }^{\text {r }}$

The second statement is made by Dr. Elliott Joslin, who has had wide experience as assistant professor of medicine, Harvard Medical School, and consulting physician, Boston City Hospital.

Granting there is a natural tendency to diabetes in certain individuals, this develops into the actual disease most commonly when the body is overfed. . . . . If the overfeeding has been in the form of sugar, predisposition to diabetes is greater. There is real danger in the candy habit. ${ }^{2}$

A comparison of these statements with the data showing the increased rate of deaths from diabetes and Bright's disease and the increased per capita consumption of sugar in the United States would seem to justify emphasis upon the three health rules under consideration.

\section{B. RECOMMENDATIONS FOR TEACHING HEALTH PRINCIPLES IN THE FOURTH AND FIFTH GRADES}

I. History.-A study of the life of the Greeks and the Romans as types of civilized society is the history work of the fourth grade in some school systems; in others it constitutes the work of the fifth grade. In either case, this phase of the course of study may be adapted to the teaching of health rules, for the athletic life of the Greek, emphasizing, as it did, strict attention to the laws of health, formed the basis of Greek literature, art, and education. The Romans, on the other hand, "though they despised athletics, realized the importance of exercise for maintaining health. The bath and the massage were the essential parts of this gymnastics and the exercises prescribed including walking, gentle running, jumping up and down, the use of halters as dumbbells, throwing the diskos and the javelin.",3

${ }^{\mp}$ R. L. Alsaker, Dieting Diabetes and Bright's Disease, pp. 9, I7, 62, 68, 92 ff. New York: Frank E. Morrison, I9I7.

${ }^{2}$ Elliott P. Joslin, A Diabetic Manual for the Mutual Use of Doctor and Patient, p. I9. Philadelphia: Lea \& Febiger, I9r9.

3 E. Norman Gardiner, Greek Athletic Sports and Festivals, p. 86. New York: Macmillan, r9ro. 
a) Greek standards of health.-The Olympic festival, which will be made the subject of this study because of its simplicity, "strict and exclusive devotion to athletics," and direct bearing upon the general life of the Greeks, was originated by an Olympic council, composed of eight and possibly nine Pisatan cities-a form of neighborhood league. Two magistrates, under the direction of the council, had charge of the athletes and, dressed in robes of royal purple, acted as judges during the festival. During the ten months preceding the contest they lived in the Umpire's Hall, receiving instruction in regard to their duties from the "Guardian of the Law." They also had charge of the money paid by the athletes who were fined for breaking the rules.

The festival lasted five days and included sacrifices, sports, and feasts. A few weeks before the festival three messengers of Zeus, wearing wreaths of olive leaves, went to all the Greek states, bidding the people to the contest. The competitors, having registered by a certain date, were required to appear before the statue of "Zeus Horkios, who was represented with a thunderbolt in his right hand as a warning to evil-doers, and there having sacrificed a pig, they swore on its entrails to use no unfair means to secure victory, and, further, that they had trained for ten months in a manner worthy of the festival.",

The old athlete lived a simple natural open-air life. Training in the strict sense he had none. His diet was mainly vegetarian. Like the diet of the country-folk in Greece at all times, it consisted mainly of figs and cheese . . . o of porridge and meal-cakes with only such meat as the occasion offered. It is possible that certain forms of foods were forbidden to competitors at particular festivals. ${ }^{2}$

After the oath, the contestants passed before the judges who decided upon their eligibility. Immediately before the contest they were addressed in the following words, which indicated the high standard to which they were held:

If you have exercised yourself in a manner worthy of the Olympic festival, if you have been guilty of no slothful or ignoble act, go on with your good courage. You who have not so practised, go whither you will.3

Because of its adaptability to health instruction and because it was the only form of competition which required an all-round

$$
\text { ' Ibid., p. } 203 . \quad \text { ' I Ibid., p. 124. } 3 \text { Ibid., p. } 202 .
$$


development, only the pentathlon, which consisted of running, jumping, throwing the discus and the javelin, and wrestling, will be discussed here. (Wrestling is, of course, impractical for the problem as set forth in the beginning of this article.) The other events are too well known in the athletics of today to need comment beyond the statement that the discus (a more or less flat piece of metal or stone) and the javelin (a straight pole about six feet long and one-half inch in diameter) were thrown either for distance or for accuracy. According to some writers, victory in three of the events was required, again showing the importance they attached to the all-round development. The Greek ideal was further exemplified by the fact that the only prize given was a simple crown (made either of olive leaves or of dried celery). The victor was allowed the privilege of placing his portrait in the gallery.

b) Roman ideals.-In the regular history of the fourth and fifth grades, the field of law and government, as illustrated by the political institutions of the Romans, is emphasized. In this connection both the private and public life of the Romans can be used for the purpose of health education.

The private life of the primitive Roman was noted for its simplicity. The majority of the people were early risers. Their breakfast was a simple one. Heavy foods, such as warm and cold meats, fish, vegetables, were rarely taken before midday. After a lunch (called prandium) taken about eleven o'clock, the entire populace retired for a midday slumber, a custom which seems to have been universal. Refreshed, they proceeded to their baths, considered at first the greatest of all luxuries, but later adopted by all. This was followed by the principal meal of the day and consisted chiefly of bread or porridge, and vegetables.

A study of the public life of the Romans is directed to its political institutions since it was the law of the city-state of Rome that has systematized the law of the world, and should, therefore, be included in the work outlined here. The permanent council was the senate, members of which were chosen part of the time by a dictator. The badges of the senators were "a tunic or a waistcoat with an oblong broad stripe of purple, like 
a ribbon, sewed to it on the fore part. . . . . In the games on the circus, the senators sat promiscuously with the other citizenstill the emperor Claudius assigned them particular seats." The presiding magistrate of the senate was the counsul. The method of voting is indicated by the words of the consul: "Let those who are of such an opinion pass over to that side; those who think differently, to this."

Certain functions of the government came under the direct control of the people, the assembly of whom was called the comitia. One of these functions was the declaration of war and the making of peace. The collection of their laws, called the Twelve Tables, included statutes upon lawsuit, thefts, robberies, the common rights of people, ceremonies, etc., but there was one law particularly related to the problem under discussion, namely, "that on ordinary days there should not be more served up at table than three pounds of fresh meat, and one pound of salt meat; but as much of the fruits of the ground as every one pleased."

It is not the purpose of this article to give details which may be in general libraries, but merely to give enough data for the purpose of discussing methods of instruction.

How, then, can this material be used? First, it is suggested that the teacher divide the class into two groups, the first group to be composed of children who are up to the standards of health, those who are of average weight and above and have no organic diseases; the second group should include those who are not in the best physical condition-the underweights, those who have diseases (such as heart disease), or those who may be recovering from illness. The first group may be called the Greeks and may be eligible to enter their names for an athletic contest arranged by the physical director. This contest may be the summary of the year's work in physical education. Children of this age, always interested in the use of new and long words, will be much more alive to the direction given by the teacher in such form as "The paidotribe (the name of the teacher who trained the Greek

I Alexander Adam, Roman Antiquities, p. Ir. New York: Collins, Keene \& Co., 1836 .

2Ibid., p. I41. 
boys from the seventh to their twentieth years) is ready to instruct the Greeks," than "The class in physical education will pass to the gymnasium."

More vital, however, is the work of the classroom. The Greeks may be divided into groups representing eight or nine Pisatan cities, each city electing a member to the "Olympic Council," which in turn elects the magistrates or judges. The teacher should be the "Guardian of the Law." Each city should draw up a set of health rules to which the trainers of the athletic contests should adhere. These rules should then be presented to the "Olympic Council" for revision and later to the "Guardian of the Law" for final suggestions. The fact that the Greek athletes slept in the open, lived largely on a vegetarian diet, and indulged in only a reasonable amount of meat, and that the contestants went into training for ten months (coincident with the length of the school year) gives the teacher the opportunity for emphasizing the health rules suggested for these grades. The actual training for the contest given at the end of the year should be the work of the physical or playground director. Thus it is possible to combine under one project, history instruction, actual physical training, strict adherence to the general rules of health, and art. (Art will be discussed later under a separate head.)

The athletic contest would, of course, be too strenuous for those who are not in the prime of physical condition. The Greeks realized this when they eliminated from their contests those who had not been in training for ten months and had not exercised "in a manner worthy of the Olympic festival." Therefore, the members of the second group described may be called the Romans. The midday rest of the Romans, coming as it did before the hearty meal, furnishes a convenient occasion for encouraging those who are undernourished to have a similar rest period. While the "Greeks" retire to the athletic fields, the "Romans" may retire for their merídiātiōo, or their midday slumber.

The political life of the Romans also comes in for its share of adaptation. Just as the "Greeks" have their "Olympic Council," the "Romans" may have their "Senate" and, after having made their badges, may have particular seats at the athletic contests. 
The function of this "Senate" may be the "declaration of war on ill-health and the making of peace with health." Their rules should be called the "Twelve Tables," and the work of engraving these laws upon the tablets of brass (gilt paper may be used) may be the work of the drawing class. Space will not permit a detailed discussion of the laws of the Romans, but it is thought that sufficient material for this purpose may be obtained from general school references. A selected list of books, in addition to those already referred to, which may be found helpful in supplying further information is here presented:

Greek Ideals: A Study of Social Life. C. Delisle Burns. New York: Macmillan Co., rgr 7 .

The Olympic Games. Theodore Cook. London: Archibald Constable Co., 1908.

Homeric Society. Albert Galloway Keller. New York: Longmans, Green \& Co., 1902.

A History of Ancient Sculpture. Lucy M. Mitchell. New York: Dodd, Mead \& Co., I883.

Harvard Studies in Classical Philology, Vol. I9. Cambridge, Massachusetts: Harvard University, Igo8.

The Private Life of the Romans. Harriet Waters Preston and Louise Dodge.

Chicago: Benjamin H. Sanborn \& Co., I893.

The Social and Private Life at Rome in the Time of Plautus and Terence. George

Leffingwell. New York: Columbia University Press, I9I8.

The Private Life of the Romans. Harold Whetstone Johnston. Chicago: Scott, Foresman \& Co., 1903.

Roman Life and Manners under the Early Empire. Ludwig Friendlander. New York: E. P. Dutton \& Co., I9I3.

2. Art.-The predominance of strength is a distinctive characteristic of the art of the early Greek period. The "Bearded Heracles" stands out as one of the most characteristic figures in the early Greek art as a "personification of endurance and trained strength, a man, as Pindar says, short of stature but of unbending soul." Pictures of the Discus Thrower, for example, may be obtained from the Bureau of University Travel, The University Prints, Newton, Massachusetts, for one cent each. The order numbers are Series A. 61, 62, and 63. These may be used as prizes in addition to the crown of olive or celery leaves.

3. Literature.-Children in the fourth and fifth grades delight in the fairy tales and old legends of other countries. While care 
should be taken not to destroy the primary purpose in reading these fanciful tales, the teacher should not lose the opportunity to include a little incidental instruction on the points which she may wish to emphasize. Reviews are especially necessary for younger children, but their value will depend to a large extent upon a new method of presentation. The following bibliography, therefore, includes material which can be used not only in teaching the essential ideas recommended for these grades but also in reviewing the health rules suggested for the first three grades.

\section{The value of health}

"The Sick-Bed Elves" (from China). Book of Elves and Fairies. Frances Jenkins Olcott. Boston: Houghton Mifflin Co., I9I8.

"The Garden of Health." Fairy Tales from Spain. J. Munos Escamez. New York: E. P. Dutton \& Co.

\section{Elimination of sweets between meals}

“The Candy Boy." The Storytellers' Magazine, Vol. 5. New York: Storytellers Co., I9I 7 .

"Who Discovered the Maple Sugar." Stories to tell The Littlest Ones." Sara Cone Bryant. Boston: Houghton Mifflin Co., I9r6.

\section{Milk}

"Bob and Betty Visit Uncle John." The Farm Book. E. Boyd Smith. Boston: Houghton Mifflin Co., Igro.

\section{Fruit}

“The Three Golden Apples." Nathaniel Hawthorne. Myths Every Child Should Know. New York: Grosset \& Dunlap, I905.

"The Apples of Idun." H. W. Mabie. Myths Every Child Should Know. New York: Grosset \& Dunlap, 1905.

“The Big Red Apple." The Story Teller's Book. Alice O'Grady. Chicago: Rand McNally \& Co., I 12 i.

"The Golden Pears." Stories and Story-Telling. Angela M. Keyes. New York: D. Appleton Co., Igr I.

"The Origin of Strawberries." Myths and Legends of the Great Plains. Edited by Katherine Judson. Chicago: A. C. McClurg \& Co., I9I3.

"How We Cut Apricots." Evelyn Hibbard. Half a Hundred Stories. Edited by Alice May Douglass. Springfield, Massachusetts: Milton Bradley Co., I907.

"Momotaro, or the Little Peach Child." Wonder Tales of Old Japan. A. L. Whitehorn. New York: F. A. Stokes Co., IgI 2.

"Why the Bananas Belong to the Monkey." Fairy Tales from Brazil. Elsie Spicer Eells. New York: Dodd, Mead \& Co., 1917. 


\section{Cereal}

"A Bowl of Porridge." Elizabeth Colson. The Storytellers' Magazine, October, I9I3. New York: Storytellers Co.

"The Discovery of the Wild Rice." Myths and Legends of the Mississippi Valley and the Great Lakes. Edited by Katherine Judson. Chicago:

A. C. McClurg \& Co., I9I4.

"Ceres." Round the Year in Myth and Song. Florence Holbrook. New York: American Book Co., 1897.

"The Roman Cereal Festivals." Corn Plants: Their Uses and Ways of Life. Frederick Leroy Sargent. Boston: Houghton Mifflin Co., I899.

\section{Vegetables}

"The Tomato Story." For the Children's Hour. Carolyn Sherwin Bailey and Clara Lewis. Springfield, Massachusetts: Milton Bradley Co., I9I6. "The Little Redcap." Book of Elves and Fairies. Frances Jenkins Olcott. Boston: Houghton Mifflin Co., I9I8.

"Old-Woman-Who-Never-Dies." Myths and Legends from the Great Plains. Edited by Katherine Judson. Chicago: A. C. McClurg \& Co., I9r3. "How Indian Corn Came into the World." The Red Indian Fairy Book. Frances Jenkins Olcott. Boston: Houghton Mifflin Co., I9r 7.

"The Spirit of the Corn. An Iroquois Legend." Harriet Maxwell Converse. Good Stories for Great Holidays. Frances Jenkins Olcott. Boston: Houghton Mifflin Co., I9I4.

"A Live Potato." The Five Senses. Angela M. Keyes. New York: Moffatt, Yard \& Co., rgrr.

"The Pea That Won the Princess." The Elm-Tree Fairy Book. Clifton Johnson, editor. Boston: Little, Brown \& Co., r908.

\section{MEASURING THE RESULTS OF TEACHING HEALTH HABITS}

As stated in the articles published in the September and November issues of the Elementary School Journal, the realization that the health program in the public school needs greater emphasis and the proof that it is possible to combine this instruction with that given in other subjects are of no avail unless the method of constantly checking results is also adopted. The details of this method have been so fully described that there is no need for repetition. It is an easy task for the teacher of the fourth or fifth grade to construct her own score card by adding to the third-grade score card the items suggested for these grades and those health principles which a survey of the needs of the individuals of her group seem to indicate should be incorporated in her health program. 